Suleman Essop Dangor

Suleman Essop Dangor is Professor of Islamic Studies, School of Religion and

Theology, University of KwaZulu

Natal, Durban, South Africa.

E-mail: dangors@ukzn.ac.za

\title{
Arabic-Afrikaans Literature at the Cape
}

\section{Arabic-Afrikaans Literature at the Cape}

Tuan Guru - the first official imam at the Cape - used Malayu as the medium of instruction in the Dorp Street madrasah (Muslim religious school) which he established at the end of the $18^{\text {th }}$ century. This changed in the middle of the $19^{\text {th }}$ century when Cape Dutch was adopted as the language of instruction. While the children were familiar with this language they could not read the Latin script since they were barred from attending the public schools. Cape Muslims could, however, read the Arabic script which they had to learn for liturgical purposes - though they could not speak Arabic. To overcome this conundrum, numerous scholars and teachers began to translate Arabic texts into Cape Dutch and then transcribing these in the Latin script. These "readers" came to serve as official textbooks in the madrasahs at the Cape. This article traces the development of this genre of literature which came to be known as Arabic-Afrikaans, comments on manuscripts that were identified by Adrianus van Selms, Achmat Davids and Hans Kähler and highlights the daunting challenge of transcribing Afrikaans phonetically in the Arabic script. Key words: Arabic, Arabic-Afrikaans, Afrikaans Literature, Cape-Dutch, Cape Muslim history.

\section{Introduction}

This article provides an overview of the emergence of a genre of literature which has come to be popularly known as "Arabic-Afrikaans" Literature at the Cape, lists the manuscripts that have been discovered and/or identified by researchers of Cape Muslim history, and highlights the challenges of transcribing Afrikaans phonetically into the Arabic script. We know from historical records that Muslims were brought to the Cape mainly from the East Indies and the coastal regions of India which were under Dutch occupation, soon after the Dutch East India Company had established itself there in the mid- $17^{\text {th }}$ century. Slaves and lawbreakers (bandiete) were to provide labour for the newly founded colony, while political exiles were isolated either on Robben Island or on farms to ensure that they did not influence their people to rebel against the Dutch (Davids 1980: 37).

Apart from being victims of Dutch economic exploitation, Muslims at the Cape were deprived of fundamental human rights, including the right to worship freely and openly. The first mosque, the Awwal Masjid (also known as the Dorp Street Masjid), was established only in 1798 (Davids 1980: 47). During the first century and a half Islam was sustained essentially through the tarigah (sufi order) (Da Costa 1994: 
131). We have clear evidence of sufi (mystic) practices at the end of the $17^{\text {th }}$ century in the form of the dhikr (chanting) sessions that Shaykh Yusuf of Macassar, a sufi master of the Khalwatiyyah Order, conducted in secret with the slaves (see Dangor 1994).

Despite the hardships and deprivations that Muslims suffered under the Dutch, a sense of community began to develop among the disparate groups. The genius of this nascent community manifested itself in various ways, including the generation of literature which came to be called "Arabic-Afrikaans" (see Ebrahim 2004). This literature flourished briefly when it first emerged in 1868-1869 and later from 1906 to 1929. However, since it was written in the Arabic script, it was naturally assumed to be in the Arabic language.

Afrikaner academics only became alerted to the true nature of this literature in the mid $20^{\text {th }}$ century, thanks mainly to Adrianus van Selms who used the designation "Arabic-Afrikaans" literature for the first time in his book Arabies-Afrikaansche Studies -'n tweetalige (Arabies en Afrikaans) kategismus ("Arabic-Afrikaans Studies a bilingual catechism") in which it was defined as "literary work which is written in Afrikaans with Arabic letters". In his Ubersicht über die Arabisch-Afrikaansche Literatur ("Survey of Arabic-Afrikaans Literature") van Selms cited ten such works. However, only two of these titles are known, Risalat fi Aqidat al-Tawhid "Treatise on the Doctrine of Tawhid") and Risalat Mushtamil 'ala Ziyarat al-Qubur ("Treatise on visiting graves") (Davids 1991c: 90). According to Piet Muller (1960: 38) at least 21 manuscripts had been discovered by 1960 . He has not provided any details though. Hans Kähler (1971) listed 51 titles in his Studien über die Kultur, die Sprache und die Arabisch-Afrikaansche Literatur der Kap-Malaien, in the chapter "Die Arabisch-Afrikaanse Literatur", stating that the titles of the remaining 13 had still to be investigated. This list is reproduced below.

Achmat Davids located an additional 14 manuscripts to Hans Kähler's 64. (Davids 1991a: 1). They include the following:

- Three student notebooks (koplesboeke)

- a manuscript by Ghatieb Magmoed

- Die Boek van Tougied by Imam 'Abd Allah ibn 'Abdurauf

- a letter by Achmat Effendi

- Tuhfat al-Atfal ("Gift for children”) by 'Abdurahim ibn Muhammad alIraki

- Tartib al-Salah ("The system of prayer") by Imam 'Abdurahman Cassiem (Qasim) Gamieldien

- a letter by Awaldien, the fezmaker

- 'I'lan (“Announcement”) - a letter by Abdurahmaan (Davids 1991c: 91-93). 
In his biography of Shaykh Isma'il Hanif Edwards, Mogamat Hoosain Ebrahim includes the following titles which have been not identified by the earlier researchers:

- Texts with Arabic titles: Irshad al-Bariyyah fi al-Hadith al-Nabawiyyah ("Guidance to Humanity on the subject of Narrations of the Prophet"); Al-MinhajalSaniyyah fi al-Lughat al-Arabiyyah ("The Sublime Benefit of the Arabic Language").

- Texts with Afrikaans titles: Die Eerste Stap ("The first step"), Die Gajjie en die Oemrah ("The Hajj and the Umrah"), Gajj Ganafie ("The Hanafi Method of Hajj"), Kitaabul Figh ("The book of jurisprudence"), Arwaag ("Souls"), Korte Begrip van die wat nodig is om te weet ("A brief explanation of what one needs to know") and Al-Islam.

Besides these texts which we will discuss in more detail below, Arabic-Afrikaans manuscripts dealing with amulets and black magic were in circulation among the learned class of the Cape Malays (Kähler 1971: 70).

\section{Reasons for emergence of this genre of literature}

When Tuan Guru, the first imam or Muslim cleric, opened the Dorp Street madrasah (religious school), the first madrasah in South Africa in 1793 he used Malayu as the medium of instruction since it had become the dominant language of Cape Muslims by the end of the $18^{\text {th }}$ century (Davids 1989: 16, 18, 24). Later, when Afrikaans came to be the preferred language of communication among Muslims in the mid-19 $9^{\text {th }}$ century, it was adopted as the medium of instruction in the madrasah (Davids 1989: 38). Davids (1989: 3) claims that Cape Muslims were among the first to speak the new language which was actually a creolized form of the Dutch spoken by Dutch authorities and their families. We shall refer to this as Cape Dutch.

However, there was one fundamental problem. Cape Muslims were familiar with the Arabic script which was essential for the purpose of reciting the Qur'an in the original language but did not understand Arabic. ${ }^{1}$ This meant that they could not access the Islamic texts in Arabic which were prescribed for the madrasah. The logical thing to do would be to translate them into Cape Dutch which the learners were conversant with. Since they could not read the Latin script because they were not allowed to attend state schools, transcribing the translated texts into the Latin script would not have resolved this conundrum.

The religious scholars at the Cape discovered a novel way in which to communicate these texts to the learners. They proposed translating Arabic literature into CapeDutch, while retaining the Arabic script so that learners would be able to read it without difficulty. The most prolific writer of Arabic-Afrikaans was Shaikh 'Abd al- 
Rahim ibn Muhammad al-'Iraqi who was known to have been an outstanding theologian (Davids 1989: 31).

It must be noted that a precedent for this genre of writing had already been established in the Malaysian Archipelago. When Sultan Muhammad Shah ascended to the throne of Malacca in 1276 he initiated a process of adapting the Arabic alphabet to Melayu. The Melayu-Arabic script is popularly known as jawi. It has been established that Melayu was the official medium of instruction in the Dorp Street madrasah. The texts that were prepared by Tuan Guru were written in Arabic with translations in Melayu in the Arabic script (Davids 1991c: 4). The question that arises is: why would Muslims choose Cape Dutch Afrikaans as their means of communication and, more importantly, what explains their willingness to translate their sacred texts into Afrikaans and then transcribe it in their sacred script, Arabic? Davids (1991c: 12) provides an answer: The Cape Muslims did not consider Afrikaans to be a foreign language or the language of the oppressor, but "as a spiritual language, on par with Malayu". More importantly, though, some of the texts were written in response to issues confronting the Cape Muslims. This is evident from some of the titles. Irshad al-Ummah li Bayan Salat al-Zuhr ba 'da al-jumu 'ah 'ala al-madhahibal- arba 'ah al-'Immah al-Mujtahidin wa hukuma 'inda al-Rawafid wa al-Wahhabiyyin ("Guiding the community by clarifying the issue of the Zuhr prayer after Jumu 'ah based on the four schools of jurisprudence of the mujtahdi imams and the wise men among the Rawafid and Wahhabis") was written in response to a dispute relating to the Friday prayer. ${ }^{2}$

\section{Kähler's list of manuscripts}

Below I have listed the manuscripts found in Kähler's work cited above. These have been arranged under the authors' names. Those whose authors are unknown have been included under Anonymous.

1. Abu Bakr Effendi: Bayan al-Din ("Explanation of Religion”).

2. Isma'il ibn Muhammad Hanif: Bughyat al-Mushtaqi fi al-Nikah wa al-Talaq ("The requisite for one who intends marrying or divorcing"); Hidayat al-Talibin fi Figh al-Din ("Guidance for those who seek to understand the faith") - this tract was written by Shaykh 'Abd Allah ibn al-Shaykh 'Abd al-Rahman Bafadl al-Hadrami; al-Qawl al-Tamm fi ma yata'allaq bi al-Mayyit min al-Ahkam ("The correct teaching relating to regulations pertaining to the deceased"); al-Qawl al-Wafir fi Ahkam Salat al-Musafir ("The valid teaching relating to regulations pertaining to the prayer of the traveller"); al-Qawa'id li Nahwiyyah li Tadris alLughat al-Arabiyyah ("Principles of grammar for teaching Arabic"); Mawlid alBarzanji ("The Barzanji mawlid"); al-Mi'raj al-Qawim fi Tajwid al-Qur'an alKarim ("The firm stairs leading to the art of reciting the Qur'an"); al-Muqaddimah al-Hadramiyyah ("The Hadrami introduction"). ${ }^{4}$ The author of this text 
was Shaykh 'Abd Allah ibn al-Shaykh 'Abd al-Rahman Bafadl al-Hadrami; Mulhak li Kitab fi Qawa'id al-Lughat al-'Arabiyyah li Musa'adat al-Talib al-Mubtadi' ("Supplement to the book on Arabic grammar to assist the new student"); al-Rawd al-Azhar fi al-Figh al-Akbar ("The radiant garden relating to greater jurisprudence"); Tuhfat li Mubtadi'in fu Usul a-Din ("Gift for those who have just started studying the principles of the faith").

3. 'Abd al-Rahman ibn al-Sayyid 'Abbas: Du'ah Kanz al-'Arsh ("Invocation of the Treasure of the Throne"). ${ }^{5}$

4. 'Abd al-Rahman ibn al-Haji Qasim ibn al-Hajji Jamil al-Din: Du'ah li Shahr Ramadan al-Mukarram ("Invocation for the revered month of Ramadan"); Kitab al-Mutala'ah li Tadris Talamidhat Madrasat Habibiyyah ("Reader for teaching pupils of the Habibiyyah madarasah").

5. 'Abd al-Rahim ibn al-Marhum al-Shaykh Muhammad al-'Iraqi: Hidayat alWahhabi li Tariq al-Sawab ("Wahhabi Guidance to the Correct Way"); Kitab 'Ilm al-Fara'id ("The book on knowledge of the obligations"); Risalat fi Bayan Fada'il Laylat nisf Sha'ban wa al-Du'ah al-Warid fiha ("Treatise explaining the virtues of the night of the middle of Sha'ban and the invocation that has been mentioned in respect of it"); Tafsir Surah Yasin ("Commentary on Surah Yasin," i.e. chapter 36); Tafsir Surah Yusuf ("Commenatry of Surah Yusuf," i. e. chapter 12); Sharh al-Musamma Kifayat al-Awwam ("Commentary on what is suitable for the general public"); Mohammedan Calendar.

6. M. A. Abrahams: al-Istighfar wa al-Tasbih ("Seeking forgiveness and glorifying God"); Qur'an: Alif Lam Mim - al-Baqarah ("The Qur'an: Alif Lam Mim, the Cow"); Surah al-Baqarah ("Chapter: The Cow," i. e. chapter 2 of the Qur'an); Hierdie Touwgied is in (3) parte in; die Kitab praat van die Islaam en die Imaan, met die Igsaan; die 2de Kitaab se vrae is: How glo jy aan Allah; en die 3de kitaab is omte maak die werk sloan met die Arkaan saam, en die Igsaan ("This Tawhid is in 3 parts: the book talks about Islam and Iman with ihsan; the second book asks: How do you believe in God, and the $3^{\text {rd }}$ book is to link action to beliefs and ihsan").

7. Muhammad 'Abd Allah: Kitab 'Alamat Kubra wa 'Alamat Sughra ("The book on great and small signs of Judgement"). ${ }^{6}$

8. Sa'd 'Abd al-Rahman: Kitab Bab al-Akhbar Hadith ("The book on the science of Hadith").

9. Adam al-Din ibn al-Hajji Muhammad Amin Taufah: Kitab al-In'am fi Bayan Arkan al-Islam ("The book on the benefits of expounding the pillars of Islam").

10. Ahmad al-Ishmuni: Kitab al-Qawl al-Matin fi Bayan Umur al-Din ("The book on the firm declaration with regard to explaining the affairs of faith").

11. 'Abd al-Rahim al-Sayyid 'Abbas: Kitab al-Ma'ruffi Bayan al-Tawhid al-Kubra ("The well-known book on explaining the greater Tawhid"). ${ }^{8}$ 
12. 'Abd al-Raqib ibn 'Abd al-Qahhar: Kitab al-Riyad al-Bad'iyyah fi Usul al-Din wa $b a^{\prime} d$ furu' al-Shari'ah ("The book on the wonderful garden relating to the principles of the faith and some branches of Islamic law"); Safinat al-Najat ("Rescue ship"), the author of which was Salim ibn Samir al-Hadrami.

13. 'Abd al-Qahhar ibn Hajji 'Abd al-Malik: Nur al-Islam ("The Light of Islam"); Tuhfat al-Ahkam ("Gift of friends").

14. Abu Bakr ibn al-Shaykh al-Imam 'Abd Allah ibn 'Abd al-Ra'uf: Sabil al-Najat ("Way of redemption") by Salim ibn Samir al-Hadrami; Dit is die Tarjaman van Fatiha en van Ayat al-Kursi en ander baiten die twee van du'as ("This is the commentary of Surah Fatiha and of the Verse of the Throne and other invocations"); Risalat fi Aqa'id al-Tawhid ("Treatise on the doctrine of tawhid"); alTanbih ila La'igat bi Ahwal al-Muslimin ("Advice on what is suitable for the conditions of Muslims").

15. 'Abd Allah ibn Taha ibn Jamil al-Din: Risalat fi Qada Shahr Ramadan wa ma yata'allaq bihi min al-Shurut wa al-Arkan ("Treatise on how to spend the month of Ramadan and the conditions and basic principles relating to it"); Masa'il Abi Laith ("Questions of Abu Laith") The author this work was Nasr ibn Muhammad ibn Ahmad ibn Ibrahim al-Hanafi (Shaykh Abu Laith); Ratib alHaddad al-Musamma al-Hisn al-Hasin ("Ratib al-Haddad called al-Hisn al-Ha$\left.\sin ^{\prime \prime}\right) .{ }^{9}$ The author of this work was 'Abd Allah ibn Alawi al-Haddad.

16. 'Abd al-Rahman Jamil al-Din (Gamieldien): Risalat Jalilat Tashtamil 'ala Qawa'id al-Islam ("Sublime treatise containing the principles of Islam").

17. Yasin ibn al-Khatib 'Abd al-Samad: Risalat Mushtamil 'ala Bayan Tariqatina ("Treatise containing an explanation of our [sufi?] way of life"). The authors of this treatise were Shihab al-Din ibn Sha'ban and 'Abd al-Rahman ibn alSayyid Abazar;

18. Hisham Ni'matullah ibn Abi Bakr: Siraj al-Idahi ("Light of elucidation").

19. Ahmad ibn Muhammad ibn Baha al-Din: Irshad al-Ummah li Bayan Salat alZuhr ba'da al-jumu'ah 'ala al-madhahib al- arba'ah al-'Immah al-Mujtahidin wa hukuma 'inda al-Rawafid wa al-Wahhabiyyin ("Guiding the community by clarifying the issue of the Zuhr prayer after Jumu'ah based on the four schools of jurisprudence of the mujtahid imams and the wise men among the Rawafid and Wahhabis"); Su'al wa Jawab ("Question and Answer").

20. 'Abd al-Rahim: "'n 5 talige woordelais en kort sinnemtjies in Arabies, Persies, Hindustani en Afrikaans-Engels" ("A word list in 5 languages and short summaries in Arabic, Persian, Hindustani and Arabic-Afrikaans").

21. Anonymous: Bidayat al-Mubtadi ("First steps for beginners"); Sharh 'ala al-Risalat al-Musammah fi Fath al-Rahman fi tajwid al-Qur'an ("Commentary on the treatise called 'With regard to the opening of [the chapter?] al-Rahman according to the art of Qur'anic recitation'"); Hujjat al-Islam ("The Proof of Islam"). 
The above list reveals the following: (a) the most prolific translators or transliterators were Abd al-Rahim ibn al-Marhum al-Shaykh Muhammad al-'Iraqi and Isma'il ibn Muhammad Hanif; (b) the manuscripts deal with Islamic doctrine, ritual, rules and regulations, social issues, explanation of Qur'anic texts and of the Prophetic Tradition, mysticism and the Arabic language; (c) the themes are consistent with "readers" designed for madrasah children; (d) the fact that tracts dealing with mysticism formed part of the madrasah curriculum not only indicates that Sufism was popular at the Cape but also that it was being consciously promoted and encouraged; (e) at least one title reflects the theological dispute that erupted between Cape Muslims on the issue of the Friday prayer.

\section{The Bayan al-Din ("An explanation of the faith")}

The Bayan al-Din is recognised as the first extant publication in Arabic-Afrikaans. The first publication is said to have been Ahmad al-Ishmuni's Kitab al-Qawl alMatin ("The book on the firm bond") (see Van Selms 1953) which was referred to in Het Volksblad on 24 February 1856 as "Die Oudste Boek in Afrikaans: Isjmoeni se 'Betroubare Woord'". Davids believes that this is mere conjecture and that the publication ascribed by Van Selms and Kähler to Ishmuni is, in fact, a translation by Sheikh Abubakr Abdurauf (Davids 1991c: 2). There is evidence, however, of "the existence of koplesboeke in Arabic-Afrikaans before the publication of the Bayanuddin" (Davids 1991c: 109). ${ }^{10}$

The Bayan al-Din of Abu Bakr Effendi (d. 1880), a Turkish Islamic scholar who was sent to the Cape by the Turkish government in 1862 to provide advice and guidance to the Muslim community which was besieged with theological conflicts, was without doubt the best known publication (Davids 1991b: 2-3). It was completed in manuscript form in Cape Town in 1869 and subsequently published in Constantinople in 1877. Davids considers it as the second and probably the most extensive publication in the early history of Afrikaans literature (Davids 1989b: 1).

The Bayan al-Din is essentially a text on Islamic law based on the Hanafi madhhab and was written specifically for learners of the Ottoman Theological school. ${ }^{11}$ The Afrikaans text is not a translation of the complete text in Arabic but a paraphrase of the original. It deals with rules and regulations pertaining to Islamic practices.

\section{Challenges of transcribing Afrikaans phonetically in the Arabic script}

One of the major challenges encountered by Arabic-Afrikaans writers was to transcribe phonetically the Afrikaans words in the Arabic script since the Arabic al- 
phabet was not adequate to convey all the Afrikaans sounds in writing. They resorted to using Persian-Turkish and Malaysian adaptations of the Arabic alphabet. However, these also did not prove adequate. They were compelled to adapt forms of the Arabic alphabet to convey distinctive Afrikaans sounds. This gave rise to a distinct Arabic-Afrikaans alphabet consisting of 29 letters that they adopted to transcribe the Afrikaans sounds. Of this number, twenty are original Arabic letters of the Arabic alphabet, four are Persian-Turkish adaptations and two Malaysian adaptations of the Arabic alphabet, and the remaining two were created to represent the " $\mathrm{kl}$ " and " $\mathrm{kr}$ " sounds (Davids 1991c: 14-15).

While the Arabic vowel indicators that are used to represent Arabic vowels, diphthongs and elongations were retained in Arabic-Afrikaans, 13 new vocalisms were created to convey Afrikaans sounds that do not exist in Arabic. This was achieved by manipulating the rules of tajwid (Arabic phonetic science) (Davids 1991c: 16). Another major challenge was to represent the " $\mathrm{e}$ " sound since this vowel does not exist in Arabic. Effendi's major contribution, according to Davids, was his "ingenious manipulation of the lettering symbols of the Arabic phonetic science of tajwid" (Davids 1991b: 5). To overcome this difficulty, Effendi manipulated the Arabic alphabet and vowel indicator system (Davids 1991b: 6).

\section{Conclusion}

The development of Arabic-Afrikaans literature illustrates how Cape Muslim scholars-cum-teachers were compelled by force of circumstances to generate a novel strategy to achieve their goal of transmitting knowledge. On the one hand, they were challenged by the inability of their students to understand Arabic which ruled out teaching through the medium of Arabic, and on the other, by their inability to read the Latin script which ruled out the use of Afrikaans textbooks. They ingeniously combined their students' ability to read the Arabic script with their ability to speak Afrikaans to create a new medium to produce texts that were accessible to them. The Arabic-Afrikaans texts which were the products of this innovation played a vital function in the transmission of the basic teachings of Islam to learners in the late $19^{\text {th }}$ and early $20^{\text {th }}$ centuries. Davids (1991c: 103) attributes the subsequent demise of Arabic-Afrikaans literature to two factors, namely the emergence of Afrikaans religious texts in Roman script and the emergence of Muslim mission schools. I believe that there are several other factors which Davids did not consider. Among the most important of these are the following: (a) the gradual switch from communicating in Afrikaans to using English as the preferred medium of communication; (b) the fact that students began travelling for Islamic studies to Arab-speaking countries such as Egypt and Saudi Arabia which meant that Arabic came to hold a place of eminence among these graduates. These 
factors rule out the possibility of Arabic-Afrikaans being revived as a medium of instruction. Davids has commented on the "profound influence" of Tuan Guru's Ma'rifat al-Islam wa'l Iman on Arabic-Afrikaans literature (Davids 1989: 13). An analysis of the legal and theological contents of these texts can be an important source of information about the influences of their authors on the ideological orientation of Cape Muslims.

Notes

1. It appears that the ability to read and write the Arabic script was widespread in the Cape Muslim community (see Davids 1989: 1).

2. Mujtahid refers to a scholar who is qualified to formulate independent decisions in theological and legal matters. Rawafid (lit.: "those who refuse") - historically the term is applied by Sunnis to the Shi 'ah; it refers to the refusal by the Shi 'ah to accept the legitimacy of the caliphate of Abu Bakr, 'Umar and 'Uthman. The Wahhabis are members of an $18^{\text {th }}$ century reformist movement founded by Muhammad ibn `Abdul al-Wahhab, a Hanbali scholar, in Arabia.

3. Mawlid (birth) refers to commemoration of the Prophet's birthday. Ja'far ibn Hasan al-Barzanji was a $14^{\text {th }}$ century Islamic poet who wrote an epic poem called "Ruwayats" which expounds the heroic deeds of the Prophet of Islam. This poem is often referred to as "Maulid Barzanji".

4. al-Hadramiyyah is derived from Hadramawt, a region south of the Arabian peninsula.

5. This term refers to a popular invocation in praise of God.

6. This term refers to signs of the Day of Judgement.

7. Davids (1991c: 2) claims that the author of this work was Sheikh Abu Bakr Abdurauf.

8. Tawhid (lit.: the oneness of God) is the defining doctrine of Islam. It means the unity and uniqueness of God as Creator and Sustainer of the universe.

9. Ratib al-Haddad refers to the litanies or spiritual hymns compiled by Abdallah ibn Alawi al-Haddad; al-Hisn al-Hasin (lit.: the invulnerable fort).

10. Koplesboeke were handwritten readers containing sections of Islamic books or texts compiled for the learners.

11. There are four major Sunni schools (madhahib, sing.: madhhab) of Islamic law. The overwhelming majority of Cape Muslims belonged to the Shafi' ite school. However, Abu Bakr Effendi belonged to the Hanafite school, so he established the Ottoman theological school where he would be free to promulgate his teachings.

Works cited

Da Costa, Yusuf. 1994. The influence of tasawwuf on Islamic practices at the Cape. In Yusuf da Costa \& Achmat Davids (eds.). Pages from Cape Muslim History. Pietermaritzburg: Shuter \& Shooter, 129141.

Dangor, Suleman E. 1994. Shaykh Yusuf of Macassar. Durban: Iqra.

Davids, Achmat. 1980. The Mosques of Bo-Kaap, Cape Town: The South African Institute of Arabic \& Islamic Research.

1989. The words the slaves made. Studies in the History of Cape Town. Cape Town: University of Cape Town.

1991a. The Afrikaans of the Cape Muslim Community from examples taken from various manuscripts, books and lithographs produced between 1860 and 1928. Unpublished paper presented at the seminar on "Approaches to the Study of Islam and Muslim Societies". Cape Town: University of Cape Town, 17-19 July.

1991b. Abubakr Effendi: His creation of the Afrikaans letter $e$ in Arabic script. South African Journal of Linguistics 19(1): 1-30.

.1991c. The Afrikaans of the Cape Muslims from 1815-1915. A Socio-Linguistic Study. Unpublished M. A. thesis. Durban: University of Natal. 
Ebrahim, Mogamat H. 2004. Shaykh Ismail Hanif Edwards - His Life and Works. Cape Town.

Kahler, Hans. 1971. Studien äber die Kultur, die Sprache und die Arabisch-Afrikaansche Literatur der KapMalaien. Berlin: Verlag von Dietrich Reimer.

Muller, Piet J. 1960. Afrikaanse Geskrifte in Arabiese Karakters. Bulletin of the South African Library 15.

Van Selms, Adrianus. 1951a. Arabies-Afrikaansche Studies -'n tweetalige (Arabies en Afrikaans) kategismus. Leiden: N.V. Noord Hollandsche Uitgewers \& Royal Netherlands Academy for Sciences (Literature Division).

. 1951b. Ubersicht über die Arabisch-Afrikaansche Literatur (Survey of Arabic-Afrikaans Literature). . 1953. ${ }^{2}$ Die Oudste Boek in Afrikaans: Isjmoeni se "Betroubare Woord". Hertzog Annale van die Suid-Afrikaanse Akademie vir Wetenskap and Kuns, 61-103. 